\title{
Para ler as cartas do Pe. Antônio Vieira (1626-1697)
}

\section{João Adolfo Hansen}

Resumo As cartas do Pe. Antônio Vieira, escritas ou ditadas em diversos lugares da América Portuguesa e da Europa entre 1626 e 1697, não são veículos neutros para sua matéria empírica, mas produtos simbólicos de uma prática escriturária integrada à "política católica" portuguesa e romana. Subordinando-se a regras da Companhia de Jesus e a interesses da Coroa portuguesa, põem em cena uma interpretação situada de suas matérias, desempenhando diversas funções em seu tempo, segundo os dois gêneros da ars dictaminis, familiar e negocial. O ensaio especifica as categorias metafísicas, teológicopolíticas e retóricas que ordenam e interpretam suas matérias. Palavras-chave Metafísica escolástica; teologia-política ibérica; retórica; ars dictaminis; corpo místico; bem comum; cartas.

Abstract The letters from Pe.(Priest) Antonio Vieira, written or dictated in several locations either in Portuguese America or Europe, between 1626 and 1697, are not neutral vehicles for their empirical substance. They are, in fact, symbolic products resulting from an official writing practice integrated to Portuguese and Roman "Catholic policy". Subordinated to the rules of the Company of Jesus and to the demands from Portuguese crow'n, the letters' content require a contextualized interpretution, since they played several roles during the period, in accordance with the two genres of ars dictaminis, familiar and official. The essay specifics metaphysical, political-theological and rhetorical catcgories that organize and interpret their content. Keywords Scholastic metaphysics; Iberian political-theology; rhetoric; ars dictaminis; mystical body; welfare; lctters. 
É cousa tão natural o responder, que até os penhascos duros respondem, e para as vozes têm ecos. Pelo contrário, é tão grande violência nāo responder, que aos que nasceram mudos fez a natureza também surdos, porque se ouvissem, e não pudessem responder, rebentariam de dor.

[Vieira, Circular à nobreza de Portugal, 31/7/1694]

Para ler as cartas que o jesuíta Antônio Vieira (1608-1697) escreveu e ditou em vários lugares da América Portuguesa e da Europa entre 1626 e 1697, é conveniente especificar a historicidade dos seus regimes discursivos. Elas não são informais. Escritas com preceitos retóricos da mímesis aristotélica, têm interpretação teológico-política fundamentada na Escolástica. E não são "literatura". Em seu tempo, a instituição literária e o conceito iluminista de autonomia da ficção não existem. Também não são as "manifestações literárias" das histórias literárias brasileiras. A teologia-política que determina o tratamento de suas matérias é outra. Não prevê o idealismo alemão, o evolucionismo e o etapismo. Outra é a metafísica que fundamenta a teleologia do seu conceito de tempo e história, que não pode pressupor o nacionalismo das histórias literárias brasileiras dos séculos XIX, XX e XXI. As cartas também não são espelhos vazios ou veículos neutros refletindo supostos conteúdos pré-totalizados na realidade empírica do século xvir. Lê-las desse modo positivista ignora sua realidade de prática simbólica cuja forma é condicionada, material e institucionalmente, pelas funções que desempenham na realidade do seu tempo'.

1 A edição mais completa da correspondência de Antônio Vieira é a de João Lúcio d'Azevedo, com 710 cartas de gêneros diversos. Cf. D’AZEVEDO, Joāo Lúcio (Coordenação e anotaçāo). Cartas do padre António Vieira. Coimbra: Imprensa da Universidade, 1925-1928, 3 t. (I, 1925; II, 1926; III, 1928). Na Introdução, o autor conta que, logo depois da morte de Vieira em 17 de julho de 1697, na Bahia, o Padre Antonio Maria Bonucci, jesuíta italiano que o ajudara a redigir o texto profético de Clavis Prophetarum, informou ao Geral da Companhia de Jesus que tinha em seu poder mais de 200 de suas cartas. Os papéis do espólio deviam incluir cópias de cartas antigas e rascunhos transcritos pelo Padre José Soares, seu colaborador na Bahia, e foram encaminhados para Lisboa, onde o Santo Ofício da Inquisição os confiscou. As 200 e tantas cartas foram confiadas ao Conde da Ericeira pelo Inquisidor Geral, Nuno da Cunha, para publicação. Com as cartas oferecidas pelo Duque de Cadaval e outras, obtidas por Ericeira e pelo Padre Antônio dos Reis, oratoriano continuador da compilação, publicaram-se, em 1735, dois tomos de cartas oferecidos, ironicamente, ao Inquisidor Geral. Com erros de impressāo, muitas foram truncadas, principalmente as referentes aos cristāos-novos 
Para lê-las historicamente, é preciso lembrar o óbvio: Vieira é um letrado. No século XVII, o termo significa mais um éthos, um caráter, que propriamente a individuação autoral do escritor das sociedades de classes constituídas a partir do final do século xviII. Pelo termo, significa-se um tipo social dotado de certas qualificações intelectuais e técnico-profissionais que situam sua prática simbólica na intersecção de uma forma qualquer de atividade religiosa, econômica ou política. É alguém capacitado pelo engenho a exercitar as "letras" e as "belas letras", definidas como os gêneros não-ficcionais e ficcionais do costume latino antigo que devem ser imitados como autoridades. Em sua prática imitativa, o letrado recebe certa qualificação produtiva e certa distinção hierárquica, variáveis conforme os graus do seu desempenho técnico, do seu envolvimento institucional e do favor de seus protetores. ${ }^{2}$ Assim, Vieira não é "autor" ou "escritor" no sentido

portugueses e ao "quarto poder", entidade que, segundo Vieira, não era fome, nem peste, nem guerra, mas causava calamidades igualmente lastimáveis no comum e particular do Reino, o Santo Ofício da Inquisiçāo. Também foi alterada a mençāo de individuos, substituindo-se o nome próprio de destinatários por uma sigla, "N.N.", ou perífrases, como "A um certo ministro", "A certa pessoa" etc. Na ocasiāo em que as cartas saíam censuradas nos dois tomos de 1735, muitas já corriam publicadas como manuscritos, que provavelmente conservavam com fidelidade as palavras de Vieira. Muitos deles se acham na coleçâo de 14 volumes, feita no século XVIII, Várias obras do Padre António Vieira, da Academia das Ciências, e no Códice 1724, do mesmo século, do Fundo antigo da Biblioteca Nacional de Lisboa. João Lúcio extraiu deles os trechos que faltavam nas cartas da edição de 1735 para reconstituir textos supostamente integrais. Aos dois tomos das cartas publicadas em 1735 juntou-se um terceiro, em 1746, compilaçāo do Padre Francisco António Monteiro, oferecido ao Patriarca de Lisboa, D. Tomás de Almeida. Em 1736, mais cartas foram editadas no livro Vozes saudosas da eloquência, do espírito, do zelo e eminente sabedoria do Padre António Vieira; e, em 1748, no volume Voz sagrada, política, retórica e métrica. Em 1827, um editor anônimo publicou a correspondência de Vieira com Duarte Ribeiro de Macedo, diplomata português (16 cartas de Macedo e 110 de Vieira). Em 1854 e 1855. saiu nova ediçāo, em quatro volumes, que incluem os dois da edição de 1735 e o de 1746. Em 1877, a Empresa Literária Fluminense publicou as 511 cartas da edição de 1854-55, pondo-as na ordem cronológica que permitiu evitar as repetiçōes existentes nas ediçōes anteriores. Muitas cartas se perderam, obviamente; do total das 710 que publicou entre 1925 e 1928, João Lúcio d'Azevedo dá notícia da existência de 344 originais, nem todos do punho do jesuíta, havendo dúvidas se as escreveu, ditou ou se fez um secretário passar a limpo um rascunho, principalmente nos seus últimos anos na Bahia, quando estava quase cego e tinha as māos quebradas. Neste sentido, a falta de unidade ortográfica e os erros gramaticais podem ser atribuídos ao próprio Vieira, mas também aos copistas.

2 Como diz Vitorino Magalhães Godinho: "O funcionalismo, que, nos seus escalōes superiores pelo menos chegara a constituir uma ordem separada - a dos letrados -, integra-se em boa parte no braço nobiliárquico

266. HANSEN, Joāo Adolfo. Para ler as cartas do Pe. Antônio Vieira 
iluminista conferido aos termos a partir da segunda metade do século xviII. Para ler suas cartas historicamente, é útil considerar o valor ou os valores da sua representação produzida pela representação e exercida como representação.

Sua sociedade é, como se deve saber, sociedade de ordens em que a pessoa, sua situação social e sua posição hierárquica são definidas por categorias da pertença a um estado, estamento, clã, casa, corporação ou grupo, não por atributos da livre-iniciativa burguesa, como os direitos individuais e a psicologia liberal. Ou seja, pessoa definida escolasticamente como unidade de três faculdades da alma vontade, memória e inteligência - iluminadas e aconselhadas catolicamente pela luz da Graça inata. E situação e posição determinadas pelas regras, categorias e signos hierárquicos do seu pertencimento a uma das partes subordinadas da totalidade do "corpo místico" do Império, mais do que pela produção de mercadorias como "criatividade", "originalidade", "autonomia estética", "autonomia autoral" "direitos autorais" etc. Vale para o Portugal, o Estado do Brasil e o Estado do Maranhão e Grão-Pará do tempo de Vieira o que Viala escreve para a França do século XVII: $o$ autor não é a figura social que justifica um imaginário de autonomia crítica associado a ela. ${ }^{3} \mathrm{~A}$ identidade social do letrado não se define especificamente num campo em separado, "o campo das letras", que pressupõe a divisão intelectual do trabalho e o trabalho intelectual da divisão da sociedade burguesa. Além de efetivamente não existirem as condições materiais e a autonomia de tal campo, o letrado sempre aparece em outros serviços. Por exemplo, advogado, desembargador, juiz, secretário de Estado, diplomata. Ou, como é o caso de Vieira, padre jesuíta. O número reduzido de documentos iconográficos onde apareçam figuras de escritores e a inexistência de qualificações como "autor" "escritor" e mesmo "homem de letras" na papelada administrativa e jurídica luso-brasileira desse tempo são um indício. O letrado é designado por outras categorias - por exemplo, da profissão (ouvidor geral, advogado, padre); da posição social (fidalgo, familiar do Santo Ofício, cavaleiro da Ordem de Cristo) e, ainda, da educação (no século xv'II,

ou sua antecâmara: a carreira leva a receber o título de escudeiro, e depois o de cavaleiro, atingindo-se o grau de cavaleiro fidalgo ou mesmo acima. Tal simbiose, parcial embora, introduz necessariamente a ambiguidade na condiçāo e mentalidade do funcionalismo. Cf. GODINHO, Vitorino Magalhāes. Estruturo da antiga sociedade portuguesa. $4^{\mathrm{a}}$ ed. Lisboa: Arcádia, 1980, p. 102-3.

3 VIALA, Alain. Naissance de lécrivain. Sociologie de la littérature à l'Âge Classique. Paris: Minuit, 1985 
"letrado" geralmente significa "formado em Cânones por Coimbra"). Veja-se, por exemplo, a carta de 29 de junho de 1689, dirigida a Antônio Luís Gonçalves da Câmara Coutinho, então governador de Pernambuco, em que o remetente diz que escreve "[...] como Antônio Vieira, como morador do Brasil, como religioso da Companhia, e como quem tem esta Província a seu cargo", 4 mas não se refere a si como "escritor" ou "autor", no sentido que hoje é dado aos termos.

António Manuel Hespanha e Maria Catarina Santos demonstram que em Portugal, no século XVII, a noção corrente de direito postulava escolasticamente que, antes de ser uma vontade (voluntas), o direito era uma razão (ratio, proportio, commensuratio, ordo, ius, juízo, prudência). Contra Maquiavel e Lutero, a doutrina fundamentava o direito ou as leis positivas do reino na luz natural da Graça inata, que tem por modelo a lei eterna de Deus. O dito "direito comum" ou "ordinário" (ius commune, opinio communis, "praxística") escapava tradicionalmente ao arbítrio da "razāo de Estado" absoluta, que era a esfera própria da vontade da persona ficta ou mystica do rei. Era consensual que o direito ordinário existia independentemente, antes da sua volição pelo rei; também era consenso que seu conhecimento e aplicação dependiam de um saber específico, que era repetido por uma categoria também específica de letrados formados no curso de Cânones ministrado pelos jesuítas na Universidade de Coimbra e repetido nos cursos superiores de Teologia de seus colégios do Brasil e do Maranhão. ${ }^{5}$

Em uma carta de 1659 para o rei D. Afonso VI, Vieira evidencia essa função do letrado jesuíta, afirmando que "os primeiros e maiores instrumentos da conservação e aumento dessa monarquia são os ministros da pregação e propagação da Fé, para que Deus a instituiu e levantou no mundo". 6 E no seu texto "Defesa do livro intitulado 'Quinto Império", de 1665-1666, declara que o Papa e os pregadores evangélicos enviados pelo Papa que agem na América são "instrumentos imediatos" da conversão do mundo que contam com o

4 Carta de 29 de junho de 1689. In: D'AZEVEDO, João Lúcio. Cartas do Padre António Vieira. Ed. cit., vol. 3, p. 572.

5 Cf. HESPANHA, António Manuel; SANTOS, Maria Catarina. Os poderes num império oceânico. In: MATTOSO, José (Dir.) e HESPANHA, António Manuel (Coord.). História de Portugal. O Antigo Regime (1620-1807). Lisboa: Editorial Estampa, 1982, $4^{\circ}$ V., p. 395-413

6 VIEIRA, Pe. Antônio. Carta LXXXVI - Ao rei D. Afonso VI, 28 nov. 1659. In: D'AZEVEDO, João Lúcio. Cartas de António Vieira. Ed. cit., t. I. 
apoio de um "instrumento temporal e remoto", um "imperador zelosíssimo", que protege os pregadores.?

No Brasil de 2007, pressupõe-se a rala e rara oposição público/privado quando se fala de "literatura", propondo-se que por aqui há "público" e que corresponde ao conjunto preexistente de individualidades teoricamente livres, generalizadas ou unificadas num todo indeterminado, "opinião pública", que se apropria livremente das obras que circulam no mercado em usos que lhes dão sentidos particulares determinados pelos direitos de sua autonomia democrática declarada na Constituição. Evidentemente, "público" não é um fato positivo e não se pode generalizar sua noção liberal para todos os tempos, como costuma ocorrer nas histórias literárias brasileiras. No de Vieira, "público" significa a totalidade das partes sociais da res publica estruturadas como exercício da representação de sua subordinação ao "bem comum" do Império. ${ }^{8}$ Ou seja: é a esfera definida como "pública" porque é nela que se dá em representação a autoridade que fundamenta as representações do "bem comum" em que "público" aparece como a totalidade da subordinação de todas as partes do Império no pacto de sujeição ao rei. ${ }^{9}$ Como totalidade jurídico-mística de destinatários integrados em ordens e estamentos pacificamente subordinados ao Estado, o "bem comum" se dá em representação nas representações produzidas como um teatro corporativista onde se revela a subordinação do próprio público para o destinatário particular. Por outras palavras, o "público" se constitui como testemunho subordinado da autoridade que lhe é dada em representaçāo nas representações, ${ }^{10}$ diferentemente do que ocorre a partir do final do século XVIII com o

7 Cf. MENDES, Margarida Vieira. A oratória barroca de Vieira. Lisboa: Caminho, 1989, p. 100.

8 HABERMAS, Jürgen. L'espace public. Quaderni. (Paris), nº18, 1992.

9 Cf. SUÁREZ S. J., Francisco. Defensa de la fe Catolica y Apostolica contra los errores del Anglicanismo. Reprod. anastática de la edición príncipe de Coimbra 1613. Versión española por José Ramón Eguillor Muniozguren, S. I. Introd. general por el Dr. Don Francisco Alvarez Alvarez, Pbro. Madrid: Instituto de Estudios Politicos, 1970, 4 V., III, IV. "A liberdade cristã não consiste em estar isentos das justas leis humanas, nem em estar imunes da justa coação do castigo dos pecados quando se cometem contra a paz e a justiça; mas consiste em uma servidāo livre, por amor e caridade, que não contradiz o regime humano, mas antes o ajuda, se efetivamente existe, e se não existe, a supre com a coação."

10 Cf. MERLIN, Hélène. Public et littérature en France au XVIle siècle. Paris: Les Belles Lettres, 1994, p. 26. "O desdobramento da esfera pública estruturada pela representaçāo está ligado aos atributos da pessoa: a insígnias (brasões, armas), a uma aparência (vestimentas, penteado), a uma atitude (maneira de saudar, comporta- 
"público" nas sociedades de classes." Incluído na totalidade pressuposta do "bem comum", cada destinatário particular é definido como membro subordinado que deve reconhecer sua posição subordinada. Assim, a representação reproduz aquilo que cada membro do corpo místico do Império já é, prescrevendo, ao mesmo tempo, que ele deve ser, ou seja, persuadindo-o a permanecer sendo o que já é. ${ }^{12} \mathrm{Os}$ traços que definem o "público" são, por isso, semelhantes aos que caracterizam o público do teatro: heterogêneo e hierarquizado, é constituído apenas pelo espetáculo que lhe é dado a ver como encenação da sua subordinação. ${ }^{13}$

Todas as cartas de Vieira pressupõem a representação. A representação é uma categoria histórica substancialista ou a forma cultural escolástica posta como mediação das práticas discursivas e não-discursivas da política católica luso-brasileira do século Xvir. Categoria tabular ou folheada, condensa princípios, dogmas, referências, preceitos e articulações de sistemas simbólicos anteriores e contemporâneos. Como mediação dos discursos, determina que as cartas reproduzam princípios teológico-políticos fundamentados na metafísica escolástica que definem as posições sociais de indivíduos e estamentos "aunados", como Vieira gosta de dizer, como "corpo místico" subordinado ao rei no pacto de sujeição. A forma do "eu" do remetente, do destinatário textual e das matérias representadas nas cartas é sempre mediada pelas categorias escolásticas que constituem a representação: identidade do conceito indeterminado de Deus, definido e posto como Causa Primeira e Causa Final da natureza e da história; analogia de atribuição e de proporção dos seres criados, dos conceitos dos seres e dos signos dos conceitos com Deus, que os cria e hierarquiza; semelhança entre todos os seres e todos os conceitos e todos os signos enquanto seres criados como efeitos pela mesma

mentos), a uma retórica (estilo do discurso, fórmulas em geral) - em uma palavra, a um código estrito de comportamento 'nobre'"

11 Cf. HANSEN, João Adolfo. Barroco, neobarroco e outras ruínas. In: Teresa. Revista de Literatura Brasileira. São Paulo، DLCV-USP, 2002: "Justamente por isso, impõe-se a normatividade retórica, que pressupōe a repetiçāo. Quando os esquemas retóricos e os temas de discursos contemporâneos encenados no discurso particular são apropriados por públicos de diversas competências - mas sempre incluídos nas normas hierárquicas do 'bem comum' desse 'corpo místico' - a recepção modela-se prescritivamente".

12 Cf. MERLIN, Hélène. Public et littérature en France au XVIle siècle. Ed. cit., p. 30

13 CHARTIER, Roger. Les origines culturelles de la Révolution Française. Paris: Seuil, 1990, p. 48. 
Causa e signos reflexos da mesma Coisa; juizo do autor, que define, analisa, diferencia e combina os predicados dos seres, dos conceitos e dos signos em enunciados retoricamente adequados como verdade e verossimilhança.

Assim, todas as cartas de Vieira são escritas com conceitos fornecidos ao engenho e ao juízo do remetente pela sua memória dos usos socialmente autorizados dos signos determinados por essa metafísica. Sendo um tipo escolástico, o remetente sempre pressupõe que o atributo do Ser divino se aplica analogicamente às coisas da natureza e aos eventos da história, tornando-os convenientes e semelhantes uns aos outros. Todos são convenientes ou semelhantes pela sua ordenação em relação ao Um ou Máximo, como Vieira repete com Santo Tomás de Aquino, pois todos são seres criados pela mesma Causa como seus efeitos. Logo, todos são também análogos da sua Causa e, em cada um deles, como análogo, a Unidade divina é posta como definição hierarquizadora de todos os outros. Assim, todas as palavras que figuram os conceitos dos seres se correspondem pela semelhança que os liga como conceitos de seres criados pela mesma Coisa, podendo valer umas pelas outras como signos reflexos. E, como todos os seres e todas as palavras são apenas semelhantes, obviamente todos são não-idênticos, o que fundamenta as formas cortesãs de diç̧ão engenhosamente aguda, que produzem relações acumuladas e inesperadas, aparentemente incongruentes, entre coisas e conceitos distanciados.

As palavras e as coisas das cartas têm interpretação teológica: Vieira aplica-lhes teologemas do Velho Testamento, do Novo Testamento e de padres e doutores da Igreja, para definir-lhes os conceitos como manifestação da luz da Graça. Na leitura, o meio material da sua linguagem é ordenado como evidentia ou dramatização vívida da Presença divina. A representação satura as formas da elocução não como "barroco", conceito estético neokantiano e positivista obviamente inexistente no século XVII, mas como exemplificação compendiária da presença amorosa da Luz divina na multiplicidade das coisas e dos conceitos aproximados nas formas.

Vieira não é iluminista e isso não deve significar que o conceito de tempo histórico das suas cartas seja mítico, cíclico ou panteísta. Muito menos que, sendo conceito formulado teologicamente, postule que o mundo histórico é ilusão. Para o remetente, Deus é o princípio de identidade comum a todos os seres em todos 
os momentos do tempo. Como sua Causa analógica, faz com que todos sejam semelhantes entre si pela proporcionalidade e, simultaneamente, diferentes pela proporção. Vieira distribui e hierarquiza as matérias das cartas segundo a identidade divina, o que implica que os homens e os acontecimentos do Velho e do Novo Testamento e os homens e os acontecimentos do Império português reflitamse uns aos outros pela relação com o único termo que apresenta sentido comum a todos. Nos diversos espaços e tempos históricos, as coisas, os homens e os eventos se distinguem em número e passam, porque finitos; mas o conceito do Deus que os cria e orienta repete-se participativamente neles absolutamente o mesmo, eterno e infinito. Logo, as cartas representam o tempo histórico do Império como o presente da progressão temporal que se abre para os futuros contingentes profetizados em eventos passados. Com a progressão, Vieira demonstra que, no acontecimento que ocorre agora, Deus está presente com o conselho de sua Luz, como já esteve nos eventos de antes. A repetição que os une como acontecimentos não é a da simples semelhança deles como acontecimentos temporais, pois a semelhança é apenas um predicado da proporcionalidade deles como espécies criadas por Deus. Nas cartas, a repetição resulta dos atos do juízo de Vieira, que escreve estabelecendo a proporção de uma medida analógica comum a eles como participação de vários graus na substância metafísica. O mundo não é ilusão: há livrearbítrio e cada evento é histórico, com ser próprio. No entanto, como o tempo é criado, nenhum evento temporal pode ter relação de igualdade com seu criador; mas todo evento apresenta proporcionalidade entre a sua natureza interior e o divino. Pensando-os por proporção, Vieira ordena os acontecimentos do passado e do presente por meio de um conceito serial de analogia que os relaciona com a identidade divina segundo vários graus hierárquicos de participação.

As cartas interpretam os acontecimentos do Império Português propondo que todos os tempos históricos são reais, com existência própria. Por exemplo, os tempos dos quatro impérios anteriores ao português - o assírio, o persa, o grego e o romano - são espécies criadas e próprias de tempo, mas não espécies idênticas do Tempo. Logo, nenhum deles se repete no presente. A única Coisa que se repete absolutamente idêntica a Si mesma em todos eles é a identidade de Deus como Causa Primeira que os orienta providencialmente como sua Causa Final, fazendo-os todos análogos hierarquizados de Si e semelhantes uns aos outros 
como entes criados. Como tipo ou sombra das coisas futuras, umbra futurarum, os tempos históricos dos impérios extintos prefiguram a Eternidade que participa neles como Luz e Protótipo. Nenhum deles já realizou o Reino de Cristo. Atual em Deus, a realização permanece contingente para os homens, que a repartem de modo incompleto. Vieira afirma que Cristo já veio uma vez e que a Providência continua a revelar em vários sinais, naturais e históricos, a eficácia da Nova Aliança para todos os homens, acenando-lhes misteriosamente com o futuro do Segundo Advento. Contra Maquiavel e Lutero, suas cartas afirmam que os homens podem contar com a Graça inata, cuja atualidade de luz natural lhes ilumina as mentes como conselho do Bem. Logo, o ato da escrita das cartas nunca se dissocia da metafísica escolástica. Ela motiva substancialmente o intelecto do remetente como porta-voz da palavra de Deus que ilumina e aconselha seu testemunho imediatamente empenhado nos assuntos temporais do Império. Nas cartas, esse providencialismo é político. Principalmente depois de 1642 , elas afirmam que a vontade de todos os indivíduos dos três estados do Império, como reto desejo do Bem, e a liberdade de todos, como servidão voluntária no pacto de sujeição, devem ser conduzidas por um rei Bragança, que vai realizar o Reino de Deus na forma anunciada do Quinto Império. ${ }^{14}$

Como jesuíta, Vieira não separa vida e obra, contemplação e prática. Todas as particularidades dos tempos curtos da sua ação como noviço no colégio jesuítico de Salvador; professor de retórica em Olinda; valido e privado de reis e príncipes portugueses; amigo de fidalgos; confessor, diplomata enviado à França, aos Estados Gerais holandeses, a Roma; orador sacro, inimigo do Santo Ofício da Inquisição, Superior de missão catequética do Maranhão e Grão-Pará, profeta e escritor de cartas evidenciam a longa duração dos modelos teológico-políticos e retóricopoéticos que ordenam as práticas dos padres da Companhia de Jesus na difusão da política católica da monarquia portuguesa entre os séculos XVI e XVIII.

14 No "Sermão dos Bons Anos", pregado em $1^{\circ}$ de janeiro de 1642 na Capela Real de Lisboa, quando comenta o versículo do Pai Nosso, adveniat Regnum tuum, venha a nós o Teu Reino, Vieira profetiza que o rei vivo e presente, D. João IV, dá continuidade ao rei morto e ausente, D. Sebastião, cumprindo a promessa feita por Deus a D. Afonso Henriques na batalha de Ourique. No momento, diz, já veio o Reino que Portugal já foi, mas ainda está por vir o Reino que Portugal há-de ser, o Quinto Império. Cf. VIEIRA, Pe. Antônio. Sermão dos Bons Anos. In: Sermōes. Porto: Lello \& Irmão, 1960, v. I, p. 315-42. 
Deliberativas, judiciais e demonstrativas, as cartas põem em cena o referencial das questões políticas, econômicas, religiosas, diplomáticas, militares, jurídicas, dinásticas e outras da sociedade portuguesa no século XVII, tratando de assuntos relativos à Casa de Bragança - D. João Iv e D. Luísa de Gusmão, D. Afonso vi e D. Maria Francisca Isabel de Saboia, D. Pedro II e D. Maria Francisca Isabel de Saboia, D. Pedro II e D. Maria Sofia de Neuburg, D. Catarina de Inglaterra, os príncipes D. Teodósio e D. Duarte -; à França de Luís xiII, Mazarino, Ana de Áustria e Luís xIv; à Espanha dos Habsburgos; à Inglaterra de Carlos I e Carlos II; aos Estados Gerais holandeses e à West Indische Compagnie; a Roma; ao Reino de Nápoles; a Florença; a Veneza; à Saboia; à Polônia; à Nova Espanha; ao Peru; a Buenos Aires; ao Estado do Maranhão e Grão-Pará; ao Estado do Brasil; ao Marrocos; a Angola; à Guiné; a Cabo Verde; ao Império Otomano; à Índia; ao Japão; a Macau e ao Pegu: "Parece que me guarda Deus para testemunha das variedades e mudanças do mundo neste século, depois de ter corrido e visto tanta parte dele"15

Dirigindo-se a destinatários particulares e institucionais, Vieira as escreve aplicando preceitos retóricos da regra da Companhia de Jesus subordinados à doutrina contrarreformista do poder monárquico. Reforçando a unidade do "corpo místico" da Companhia e o pacto de sujeição do Império, suas cartas tratam do presente das suas matérias: a guerra e as negociações diplomáticas com os Estados Gerais holandeses sobre Pernambuco; a guerra e a conspiração contra a Espanha; os acordos com a França; os capitais judaicos; a liberdade de índios; a escravidão de negros; a corrupção dos grandes; a crise da produção açucareira do Estado do Brasil; a seca, a fome, o cometa, a doença, a falta de moeda e a profecia. A interpretação das matérias sempre pressupõe a teologia-política da política católica antimaquiavélica, antiluterana, anticalvinista e antianglicana, reproduzindo ortodoxamente a doutrina do tratado sobre o pacto de sujeição, Defensio fidei, publicado em 1614 pelo jesuíta Francisco Suárez, e a do tratado Della Raggion di Stato, editado em 1588 pelo jesuíta Giovanni Botero, sobre a "razão de Estado" absolutista e o "interesse", que fundamenta antimaquiavelicamente o corporativismo das práticas mercantilistas portuguesas.

15 Carta de 24 de junho de 1691 para Francisco de Brito Freire. Conselheiro de guerra e Almirante da Armada Real, em cuja qualidade passou duas vezes ao Brasil, Freire é autor de Nova Lusitânia. História da Guerra Brasilica, de que publicou a primeira parte em 1675. 
Quando as escreve, Vieira aplica a memória da educação que recebeu no seminário da Companhia de Jesus. O programa de ensino da Companhia, sistematizado no Ratio studiorum, de 1599, prescreve a educação homogênea dos padres por meio do estudo das autoridades canônicas da Igreja e das autoridades lógicas, dialéticas, gramaticais, poéticas, retóricas, históricas e prudenciais antigas, principalmente as latinas. As disciplinas do Ratio desenvolvem a memória, a vontade e a inteligência do padre, tornando-o capacitado para desempenhar os interesses da Companhia, da Igreja e da Coroa nas coisas do grande teatro do mundo. Para Vieira, é impensável a possibilidade de escrever cartas autonomizadas da sua educação escolástica e da disciplina da sua Ordem, que impõem e delimitam o "dever ser" de sua ação nos negócios temporais. $O$ remetente das suas cartas é um tipo social previsto e determinado pelas Constituições e Regras da Companhia: realiza publicamente o vínculo de obediência à sua Ordem ao aplicar os mesmos padrões retórico-doutrinários aprendidos por todos os outros jesuítas contemporâneos que também fizeram o seminário, Teologia e os votos. ${ }^{16}$ Assim, é autor, como tipo que emula na escrita os saberes de uma educação comum regrada como imitação de autoridades. ${ }^{17}$

Evidentemente, seu tempo não conhece a divisão do trabalho intelectual e o trabalho intelectual da divisão iluministas e pós-iluministas. Como tipo especificado pelo caráter e decoro de jesuíta subordinado a uma ordem religiosa subordinada a Roma e à Coroa, tem a posse das cartas que escreve, como autoridade do desempenho de seus gêneros, mas não a propriedade delas. Atribuídas à sua auctoritas, não têm originalidade, no sentido liberal da mercadoria que concorre com outras

16 Cf. LOYOLA, Santo Inácio de. Constituições da Companhia de Jesus. Trad. e notas de Joaquim Mendes Abranches, S.J. Lisboa: Província Portuguesa da Companhia de Jesus, 1975. Veja-se, por exemplo: [109]: "Para exercer o ofício de semeador e ministro da palavra divina e se dedicar à ajuda espiritual do próximo, convém ter suficiente cópia de conhecimentos intelectuais" (p. 63); [111]: "Para maior humildade e perfeição dos homens de letras, Coadjutores espirituais e Escolásticos, se houver dúvidas sobre a suficiente aptidão de algum dos candidatos à Companhia para nela ser Professo, Coadjutor espiritual ou Escolástico, deverá ter-se em conta que é muito melhor e mais perfeito para ele deixar-se julgar e governar por ela. Esta saberá, tão bem como ele, o que se requer para viver nela; e o súbdito mostrará maior humildade e perfeição, e dará provas de maior amor e confiança naqueles que o devem governar" (p. 64).

17 Cf. [814]: "Assim, devem-se cultivar cuidadosamente os meios humanos ou os adquiridos com o próprio esforço, especialmente uma doutrina fundada e sólida, e a maneira de a apresentar ao povo em sermões e lições sacras, e de tratar e conversar com as pessoas". Ibidem. 
originalidades no mercado de bens culturais. $\mathrm{O}$ remetente transforma matérias sociais com preceitos objetivos que não são de sua propriedade particular, mas propriedade comunitária da Companhia de Jesus e do "bem comum" do todo objetivo do corpo místico do Império: as autoridades da oratória, Demóstenes, Isócrates, Cícero, Crisóstomo, Paravicino; as da epistolografia, Cícero, Sêneca, Demétrio de Falero, Hugues de Saint-Victor, o Anônimo de Bolonha, Erasmo, Vives, Fabri, Justo Lípsio; as da poesia, Virgílio, Ovídio, Camões; as da história, Tito Lívio, Suetônio, Tácito; e a infinidade das autoridades canônicas da Patrística, da Escolástica e da chamada "Segunda Escolástica" dos séculos XVI e XVII.

Escritas nos dois gêneros, familiaris e negotialis, especificados na arte antiga de escrever cartas, a ars dictaminis, as cartas figuram as pessoas do remetente e dos destinatários imitando sua fala, caracteres e afetos como "pessoas naturais". A carta familiar trata de matérias civis, geralmente assuntos do interesse do remetente e do destinatário. É sermo, "fala", na definição de Cícero, ou colloquium, "colóquio", segundo Erasmo, sobre assuntos discutidos entre amigos ausentes. Como diz Demétrio de Falero, é a metade de um diálogo em que se representa a voz do remetente para o interlocutor ausente, respondendo a uma necessidade ou interesse momentâneos; ou complementando uma instrução qualquer sobre um ponto determinado. Substituindo a comunicação oral de uma visita pela escrita, a carta é breve, em estilo simples e claro, pois o destinatário não está presente para expor dúvidas quanto ao que comunica.

O gênero negocial é prescrito para matérias de interesse institucional e geral, admitindo e exigindo, muitas vezes, a dissertação, a erudição, a polêmica e os estilos ornados. Seu destinatário é "pessoa não-familiar" Como a epístola, a carta negocial pode ser bastante extensa, devendo citar autoridades canônicas e exemplos que autorizam o remetente a compor e comunicar discursos doutrinários e políticos de maneira verdadeira e verossímil. ${ }^{18}$

18 Evidentemente, a correspondência escrita como carta familiar pode ser apropriada e divulgada como carta negocial. Em 1659, quando estava em Camutá, na Amazônia, Vieira escreveu uma carta para o jesuíta André Fernandes, depois Bispo do Japão, em que expõe sua interpretação profética das trovas de Gonçalo Anes Bandarra, um sapateiro português do século XVI, para demonstrar que o rei D. João IV, morto em 1656, ressuscitaria. Vieira a enviou como carta familiar e André Fernandes deveria entregá-la à rainha viúva, D. Luísa de Gusmão, para consolá-la. A Inquisição portuguesa interceptou o manuscrito e leu-o como carta negocial, 
Considerando-se a destinação familiar e negocial das cartas de Vieira, é possível distribuí-las por três conjuntos:

1. Cartas para a Companhia de Jesus Nelas, o remetente Antônio Vieira, definido como o tipo social de jesuíta da Província do Brasil e da Província do Maranhão e Grão-Pará, escreve cartas familiares e negociais na Europa (entre 1642 e 1650; entre 1662 e 1680); na Bahia (em 1626 e entre 1681 e 1697) e em São Luís, Belém, Camutá e outros sítios amazônicos (entre 1651 e 1661), para destinatários jesuítas, como superiores da Província do Brasil, da Província Portuguesa e da sede romana da Companhia.

Quando as escreve, Vieira obedece a preceitos retóricos e disciplinares fixados no século xvi pelos padres Inácio de Loyola e Juan de Polanco para a escrita de correspondência. Escreve informando sobre o estado de coisas da missão jesuítica e reiterando os vínculos internos de solidariedade que o unem a seus irmãos em Cristo no "corpo místico" da Companhia. Familiares ou negociais na origem, suas cartas se integram na circulação mundial das comunicações do "corpo místico" da Ordem como exemplum da espiritualidade da devotio moderna antimaquiavélica, antiluterana e anticalvinista que repete, nas variadas circunstâncias da ação da Companhia, o dogma da luz natural da Graça inata, a afirmação da infalibilidade do papa como vicarius Christi, a subordinação do remetente ao rei como membro do padroado português, a doutrina suareziana do pacto de sujeição e virtudes definidas catolicamente, prudência, obediência, humildade, amor ao próximo, caridade. E, sempre, dissimulação honesta, técnica de ocultar a verdade, oposta à simulação maquiavélica, definida como técnica de produzir o falso.

2. Cartas para a sociedade colonial Nelas, o remetente Antônio Vieira, definido como o tipo social de jesuíta da Província do Brasil e da Província do Maranhão

pública e doutrinária, acusando Vieira de heterodoxia. A Igreja Católica proíbe a aplicação do método patrístico-escolástico de interpretação alegórica ou figural a textos não-canônicos e para os inquisidores foi fácil constituir o erro de Vieira. 
e Grão-Pará, escreve cartas familiares para particulares e cartas negociais para membros de instituições da sociedade colonial, em vários momentos entre $1626 \mathrm{e}$ 1697, principalmente nos anos 1651-1661, quando Vieira está no Maranhão e GrãoPará, e 1681-1697, quando está na Bahia.

Neste grupo, encontram-se, por exemplo, as cartas negociais dirigidas ao procurador do Brasil, tratando da questão indígena; à Câmara do Pará; ${ }^{19}$ e a carta familiar ao chefe índio Guaquaíba ou Lopo de Sousa. Nelas, Vieira expõe a posição jesuítica quanto às práticas de captura de índios por bandeirantes; quanto à escravização e exploração de indígenas de aldeias da Companhia por coloniais escravistas; quanto à escravização de "índios de corda", prisioneiros de grupos inimigos, que aguardam o sacrifício em que serão comidos; quanto à manipulação das leis portuguesas que regulam o direito da "guerra justa" contra as tribos consideradas "bárbaras" etc. O remetente expõe sua versão doutrinária sobre os temas, recorrendo às autoridades canônicas da Igreja como aval da autoridade de seus juízos sobre as ações de governadores e outros funcionários da administração portuguesa; de sacerdotes de outras ordens religiosas, como os carmelitas e os mercedários do Maranhão; e de outros homens da sociedade colonial. Defendendo a posição da Companhia de Jesus, as cartas tratam das questões judicialmente, tentando persuadir o destinatário da justeza e justiça das razões do remetente sobre erros e culpas dos tipos envolvidos. Em geral, o remetente propõe deliberativamente, com argumentos éticos fundamentados na metafísica cristã, que o destinatário mude de posição quanto à escravização de índios. Fundamenta-os providencialmente, afirmando que Deus confiou a Portugal a missão de integrar o gentio ao grêmio da Cristandade.

19 Vieira escreve a carta como Superior das Missões, respondendo a uma representação dos vereadores de Belém que, alegando a miséria da população, pedem que autorize uma entrada no sertão para resgatar "índios de corda". A carta é inicialmente judicial, pois Vieira julga o pedido, examinando causas da miséria alegada e motivaçōes dos indivíduos com franqueza e ironia: "[...] as necessidades que Vossas Mercês representam não sāo gerais em todos". A partir da metade da carta, pondera deliberativamente, dizendo concordar com as entradas que resgatem "indios de corda". Sua razão, no entanto, é outra: declara que "[...] os missionários não nos metemos na repartição dos escravos nem nos preços deles", mas admite que os escravos dos índios "se podem trazer para o grêmio da Igreja e o serviço da república". 
3. Cartas para a Corte portuguesa Nelas, o remetente Antônio Vieira, definido como o tipo social de jesuíta da Província do Brasil e da Província do Maranhão e Grão-Pará, escreve cartas familiares e negociais para destinatários da Corte portuguesa em Lisboa e de outros lugares da Europa, como Rouen, Paris, Haia e Londres, em vários momentos, principalmente entre 1642-1697.

Neste grupo, acham-se as cartas encaminhadas ao rei D. João IV, ao rei D. Afonso VI, ao rei D. Pedro II, à rainha D. Luísa de Gusmão, ao príncipe D. Teodósio e outros membros da casa real portuguesa, como a rainha D. Catarina de Inglaterra e a rainha Maria Sofia de Neuburg, além de fidalgos e diplomatas portugueses, como o Marquês de Niza, o Duque de Cadaval, Francisco de Sousa Coutinho, embaixador nos Estados Gerais holandeses, e Duarte Ribeiro de Macedo, amigo de Vieira. No caso, o remetente reitera sua posição de jesuíta discreto, caracterizado pela prudência e agudeza empenhadas na manutenção do "bem comum" do Império. Escreve, no caso, como típico secretário de Príncipe renascentista, representando com o conceito engenhoso os afetos discretos de sua posição subordinada no pacto de sujeição. A elegância do estilo associa-se à distinção do remetente como diplomata enviado à França e aos Estados Gerais holandeses e também a seu poder como valido de reis e rainhas, como D. João IV e D. Luísa de Gusmão, e privado de grandes do reino, como o Marquês de Niza, o Duque de Cadaval, o Marquês de Gouvêa e outros.

Três coisas distinguem as cartas familiares das negociais nesses três conjuntos: a matéria, a forma e o tema. Genericamente, a matéria da carta familiar são as coisas civis da vida de relação, diferentemente das coisas especulativas, doutrinárias ou próprias da política da "razão de Estado" da carta negocial. As diferentes matérias tratadas nas cartas familiares e negociais restringem-se aos três gêneros da persuasão oratória. Pressupondo-os, a forma da carta é determinada pela finalidade com que se trata a matéria. Para que escrever sobre a devolução de Pernambuco aos holandeses? Para aconselhá-la. Logo, a forma é de gênero deliberativo, aconselhando a medida e desaconselhando outras, com tópicas e afetos de esperança e medo. Para que escrever sobre a morte? Para advertir sobre os fins últimos do homem. Assim, a carta é de gênero demonstrativo, fazendo o louvor da virtude cristã e a acusação da vaidade, com tópicas e paixões de elogio 
e vitupério. Para que escrever sobre os colonos do Maranhão? Para acusá-los de injustiça. Portanto, a carta é de gênero judicial, acusando-os de prevaricação e defendendo a justiça das ações do remetente e de sua Ordem, com tópicas de certo e errado. Obviamente, numa mesma carta, um dos gêneros é o principal e os outros, acessórios.

Nos dois gêneros de cartas, para persuadir o destinatário da verdade do que comunica, o remetente faz referências à circunstância da escrita e ao procedimento técnico - "imitação da fala própria de pessoa natural" - que especifica seu tipo de padre jesuíta. Ao fazê-lo, obedece a preceitos disciplinares da Companhia de Jesus. Em 1542, numa carta escrita de Roma para o Pe. Fabro, então na Alemanha, o Pe. Inácio de Loyola determinou que os religiosos das diversas missões mundiais da Companhia deveriam escrever uma "carta principal", que pudesse ser mostrada a todos. Devia visar o serviço de Deus e, para tanto, não podia tratar de coisas impertinentes, devendo ter ordem coerente para servir à edificação de seus leitores. Devia ser escrita e re-escrita, corrigida e recorrigida; seu autor devia imaginar que todos iam lê-la. ${ }^{20}$

A determinação de correção e re-escritura evidencia o rigoroso controle técnico e doutrinário exercido sobre as matérias e os estilos; e também a plena consciência do efeito persuasivo que a carta deve produzir no ânimo do destinatário. $\hat{E}$ trabalhoso sempre escrever uma carta principal e Loyola chama a atenção para o fato de a escrita permanecer como um testemunho, não sendo tão fácil de emendar como a fala. Admite que a carta principal tenha anexos, nos quais é possivel escrever concertado ou sem concerto, conforme a "abundância do coração". Ele mesmo, informa ao Pe. Fabro, tinha acabado de enviar 250 cartas para vários lugares do mundo. Em março de 1555, em uma carta para o Pe. Roberto Claysson, censura-lhe severamente o estilo, afirmando que deixa de ser conveniente por ser muito ornado. No caso, Loyola distingue o estilo da eloquência profana do estilo próprio dos religiosos. Como os adornos de uma matrona que "respira gravidade e modéstia", o estilo dos soldados de Cristo deve ter uma "facúndia grave e madura", jamais "exuberante e juvenil" Se for copioso, a abundância deve ser de ideias 
ou coisas da invenção, não das palavras ou ornatos da elocução. ${ }^{21}$ Assim, Loyola prescreve um decoro que retoma a definição da carta familiar como sermo ou "fala simples" feita por Cícero e pelos autores medievais da ars dictaminis.

A simplicidade deve ser como que casual: o artifício deve parecer não-artificial. Assim, as partes devem ter disposição ordenada e gramaticalmente correta, ajustando a gravidade própria da enunciação da persona de um padre à simplicidade das palavras como aval verossímil da verdade. Deve aproximar-se da sublimitas in humilitate, o "sublime no humilde", definido por Bernardo de Claraval como estilo que testemunha a participação divina nas coisas humildes. Como a carta torna edificante a matéria tratada, constitui o destinatário como sinônimo do éthos do remetente como vir bonus peritus dicendi definido por Quintiliano. Virtuoso, moralmente qualificado para falar, demonstra autoridade ao dar sentido edificante aos temas.

Assim, enquanto aplicam o decorum específico da imitação do oral por um tipo grave, as cartas estabelecem a qualidade das causas das matérias, analisando seus temas particulares para especificar descritivamente os atributos sensíveis dos seres e eventos como motivos tratados sem atavios. Com a figuração pouco ornada, produzem um análogo sensível do éthos ou caráter aplicado para representar a humildade do remetente. A escrita é circumscriptio ${ }^{22}$ : um esboço ou resultado sensível das operações do juízo do remetente que, prudente, regula eticamente o que diz como proporção retórica "simples" Como consequência, o decoro que ordena a carta também é conveniência política ou adequaçāo à hierarquia.

A proporção decorosa do duplo padrão de humildade e sublime evidencia para o destinatário que o estilo corresponde à equidade da prudência do remetente. Sua

21 lbidem

22 Santo Tomás de Aquino. Ética, 1.7. Como uma espécie de esboço exterior do bonum finale hominis, quod est felicitas, a circumscriptio de Sto. Tomás é, conforme a interpretação de Wesley Trimpi, "notification of a thing by means of characteristics it shares with other things rather than by means of its own special attributes. For this reason, one speaks 'figuratively' first, that is secundum quandam similitudinarium et extrinsecam quodammodo descriptionem, and then fills in later what fuit prius figuraliter determinatum". Cf. TRIMPI, Wesley. "The quality of fiction: The rhetorical transmission of literary theory" In: Traditio. Studies in Ancient and Medieval History, Thought and Religion. New York: Fordham University Press, 1974, v. XXX, p. 35. Deste modo, a figuração em estilo humilde postula a necessidade da sua exegese pelo destinatário que, na aparência disparatada da multiplicidade de seres descritos e eventos narrados, deve encontrar o fundamento divino da prudência do éthos humilde que os escreve. 
enunciação produz a circumscriptio simples e prudente do seu caráter como figuração analogamente proporcional do sublime da Verdade metafísica que o fundamenta e aconselha. É discurso que se sabe fundado de direito na Verdade do seu princípio. Logo, os enunciados representam matérias presentes e, simultaneamente, prefiguram futuros contingentes. Por exemplo, as cartas sobre a catequese e a escravização de índios do Estado do Brasil e do Estado do Maranhão e GrãoPará particularizam narrativamente seus processos polêmicos; ao mesmo tempo, porque o remetente insiste na missão de conduzir o gentio ao corpo místico da Cristandade confiada por Deus a Portugal, prefiguram a realização da mesma, alegando os livros bíblicos e as formas, sacramentos, ministérios e ritos da Igreja, visíveis na instituição do Padroado. Imaginando-se dois eixos da referência do discurso - um eixo horizontal, representativo, e outro vertical, avaliativo - no primeiro deles o remetente discorre sobre coisas, pessoas, ações e eventos empíricos, para interpretar-lhes a multiplicidade e as diferenças por meio da unidade da significação divina que figura no segundo, dotando-os do sentido transcendente do qual eles também são figuras providencialmente orientadas como prenúncios do projeto divino no tempo histórico português.

Como imitação da fala de um tipo religioso, o caráter prudente do remetente é constante; por vezes, a carta aplica afetos incidentais e provisórios ${ }^{23}$ para figurar paixões que o agitam momentaneamente, desânimo, cansaço, ironia, orgulho, tristeza, indignação, espanto etc. Construindo tecnicamente efeitos de informalidade afetiva, a carta busca certa elegância sem ostentação adequada à gravidade do caráter do remetente.

Todas as cartas de Vieira podem ser analisadas por meio da fórmula da proposição "Alguém diz algo sobre alguma coisa para alguém" Na fórmula, a expressão "alguém diz para alguém" corresponde ao contrato enunciativo. Nele, a pessoa do remetente, "eu", estabelece contato escrito com a pessoa do destinatário, "tu", falando-lhe por meio de procedimentos técnicos, retóricos, e princípios doutrinários, teológico-políticos, com que seleciona, compõe e interpreta as matérias. A pessoa textual do "eu" do remetente, Antônio Vieira, é o ponto de convergência e condensação de princípios e preceitos doutrinários da Coroa e da Companhia

23 O nome do procedimento é patopeia. 
de Jesus. Eles constituem sua representação como tipo de uma ordem religiosa do Padroado português, dotando-o de um caráter ou éthos constante, prudente e agudo, discreto. Sua posição social de discreto é constituída e confirmada pelos signos ostensivos da sua submissão política e simbólica à Igreja e ao rei, que autorizam a prática da escrita feita em prol do "bem comum" da Companhia de Jesus, da Igreja e do Império.

Sendo caracterizado pelas virtudes letradas do padre e, muitas vezes, pelas virtudes galantes e heroicas do cortesão, ${ }^{24} \mathrm{o}$ "eu" do remetente distingue-se de outros "eus" contemporâneos pelo engenho e pelo juizo. O engenho, definido em seu tempo como a faculdade intelectual da invenção retórico-poética, caracteriza-o como tipo perspicaz, que analisa dialeticamente as matérias para distinguir suas propriedades e fazer definições precisas de seus temas, e versátil, que lhes dá elocução retórica ou forma discursiva conveniente. Quanto ao juízo, caracteriza-o como tipo capacitado a fazer avaliações ético-políticas da ocasião da escrita e das matérias tratadas. Assim, as três faculdades que constituem a sua pessoa como remetente - vontade, memória, inteligência - são orientadas escolasticamente como recta ratio agibilium, ${ }^{25}$ a reta razão das coisas do agir, a prudência. $\mathrm{Na}$ composição do seu caráter prudente, evidencia-se o conceito ciceroniano de virtus exposto em De officiis, traduzido no século xv pelo Infante D. Pedro, Duque de Coimbra: o remetente tem a excelência humana obtida por meio de uma educação de retórica, poesia, história e filosofia antigas. Comunica as coisas da carta para o destinatário com a recta ratio factibilium, a reta razāo das coisas do fazer, a perícia do domínio técnico da linguagem. Assim, a situação e a posição sociais do seu tipo - padre jesuíta prudente, engenhoso e ajuizado - são formalizadas como representação de um lugar institucional cujo agir e cujo fazer põem em cena os princípios éticos, jurídicos, retóricos e teológico-políticos da monarquia portuguesa e da Companhia de Jesus que o autorizam a escrever como religioso do Padroado. Simultaneamente, os mesmos princípios dramatizam a posição de sua representação particular na hierarquia, evidenciando seus limites prefixados pela representação dos seus privilégios, que exerce como jesuíta autorizado a tratar dos assuntos do Império. Como

24 Nos Estados Gerais holandeses, Vieira veste-se à moda cortesã, com grã escarlata e espadim.

25 Cf. Tomás de Aquino. Summa theologica, $\left.{ }^{|a|}\right|^{\text {ae }}$, q. 57. 
gênero do discurso próprio da pessoalidade, em oposição à história, gênero impessoal, a carta sempre tem índices da pessoa "Antônio Vieira". Os traços biográficos que constituem a primeira pessoa do remetente e o individualizam como "Antônio Vieira" devem ser entendidos como partes abstraídas do todo social objetivo, ou seja, como representações de posições institucionais estilizadas discursivamente pelo autor, não como expressão informal da sua suposta psicologia. Suas características biográficas e seus afetos intensos são etopeia, ficção retórica de uma fala de "pessoa natural" que especifica o discurso como sermocinatio. ${ }^{26}$ Obviamente, Vieira não é cartesiano. Os conceitos que formula não são expressão imediata de ideias claras e distintas de sua consciência, mas dramatização de várias espécies de imagens mentais, "fantasmas" ou conceitos, que seu juízo seleciona em elencos de conceitos e aplica, objetivamente, segundo as adequações socialmente partilhadas de clarezas e hermetismos específicos dos estilos. Nas cartas, há clarezas diferenciais, no plural, não uma só clareza univocamente definida como expressão psicológica de uma consciência que "pensa claramente". O remetente não expressa conceitos, mas escreve com conceitos expressos. Por outras palavras, a carta é aplicação e desenvolvimento argumentativo de conceitos mediados pela arte de agir e arte de fazer partilhadas pelo remetente e destinatário como preceitos simbólicos do todo social objetivo. Sua enunciação refere, com a prudência do decoro do seu tipo, também a gravidade das tarefas executadas com a obediência, a paciência e a perseverança próprias de um homem de Deus; simultaneamente, inscreve as tarefas na Palavra essencial de que recebem participativamente a legitimação.

As posições representadas do remetente o definem como tipo objetivamente incluído como posição interessada nas práticas contemporâneas em que recebe classificações positivas e negativas segundo a contrariedade dos interesses envolvidos: “jesuíta", "superior da missão do Maranhão", "pregador da Capela Real", "secretário", "confessor de reis", "valido do rei D. João Iv" "diplomata", "orador", "monstro do engenho", "príncipe dos pregadores", "profeta", "homem de muita lábia", "herege", "amigo de judeus", "Judas do Brasil" etc.

Cf. Quintiliano. Instit. Orat. 9,2,29- "fictiones personarum"; Isidoro de Sevilha. Etymologiae. 2,14,1-2 "ethopoeiam vero illam vocamus, in qua hominis personam fingimus pro exprimendis affectibus aetatis, studii, fortunae, laetitiae, sexus, maeroris, audaciae..." 
Logo, quando constitui o destinatário, o remetente o modela como um intelecto ajuizado que conhece o artifício técnico aplicado, evidenciando que o ponto de vista pessoal encenado na enunciação não é uma categoria psicológica, mesmo quando a carta é familiar, mas a perspectiva de um estilo objetivamente usado como instrumento de representação e comunicação de tipos compostos retoricamente por meio de caracteres éticos subordinados ao "bem comum" do Império. O caráter constante do remetente é indicativo do modo como seu tipo se posiciona socialmente na hierarquia. ${ }^{27}$ Seu ponto de vista sobre as matérias narradas não é autônomo, mas o da liberdade de aplicação de preceitos técnicos e doutrinários situada num intervalo elocutivo sempre subordinado doutrinariamente aos dogmas da sua Igreja e delimitado retoricamente pela inépcia, de um lado, e pela licença poética, doutro.

A "experiência subjetiva" do autor da carta é, enfim, uma variação posicionada como parte do todo social objetivo. Os modos da sua representação estão imediatamente relacionados com os meios da sua avaliação correntes no campo semântico geral de sua sociedade. Sendo uma variante da memória social dos usos autorizados dos estilos, seu estilo particular inclui-se na partilha coletiva de uma tipologia estilística que é simultaneamente uma topologia hierárquica. Evidencia o que se pode chamar de "retórica do comportamento" generalizada na sociedade luso-brasileira do século xviI como pragmática hierárquica ordenadora dos hábitos dos corpos. Como os outros discursos de seu tempo, teatraliza o corpo político do Império como unidade da subordinação ou unitas ordinis escolástica. A representação é, por isso, "teatral", propondo ações e aparências adequadas às diversas ocasiões como representações verossímeis que devem ser representadas. Sua fundamentação é a da jurisprudência escolástica de dominicanos e jesuítas que, no século XVI e durante todo o século XVII, doutrinam e afirmam, contra Maquiavel, Erasmo, Lutero, Calvino e Melanchton, que a monarquia é um "corpo místico" de ordens subordinadas à cabeça real no pactum subjectionis, segundo a doutrina suareziana do contrato social pelo qual a comunidade se

27 A autoridade da preceptiva é total. Vieira afirma: "Assim o tinha eu imaginado com algum receyo, por ser pensamento sem Author; quando venturosamente o fui achar em Santo Agostinho no livro 2 de Trinitate. onde excita, \& resolve a questão pelo mesmo fundamento" (Sermão de Santo Antônio, 1656). 
aliena do poder na persona ficta ou mystica do monarca. Logo, as formas dos decoros são absolutamente fundamentais, pois classificam, separam e ordenam hierarquicamente os indivíduos e os estados desse corpo. Distinguindo, o decoro é discreto, como decoroso e discreto deve ser o estilo. Signo evidenciador do engenho e do juízo, o estilo associa-se à prudência, virtude intelectual que controla os apetites individuais garantindo a concórdia e a paz do todo subordinado do Império.

Para informar o destinatário adequadamente, o remetente subordina os enunciados à função retórica da utilidade, recorrendo a lugares-comuns do gênero adotado, a uma ordem coerente e ao estilo simples, desataviado e breve, nas cartas familiares; e ao medíocre, claro e didático, nas negociais. A clareza elocutiva deles é prescrita como adequada para compor a perspectiva com que o destinatário recebe e avalia as matérias narradas. Para tanto, o remetente sempre compõe três tipos de destinatários: inferior, igual e superior. Na saudação deles, no início das cartas, evidencia-se a aplicação dos preceitos do decoro das artes dictaminis: dirigida a superior, a carta não pode ser jocosa; a igual, não pode ser descortês; a inferior, não deve ser orgulhosa.

Quando o destinatário é de posição superior à do remetente - caso do rei, rainhas, príncipes, aristocratas portugueses, governadores, bispos, arcebispos e superiores da Companhia de Jesus - as cartas subordinam o tratamento das matérias à afirmação reiterada da irrestrita subordinação do remetente ao "bem comum" do Império, à "razão de Estado", à etiqueta cortesã e ao "corpo místico" de sua Ordem. Quando escreve para destinatários institucionalmente inferiores, caso do chefe índio Guaquaiba ou Lopo de Sousa, o remetente o faz com índices paternais de benevolência e afabilidade. ${ }^{28}$ Quando o destinatário é igual, como outro padre da Companhia de Jesus ou o amigo Duarte Ribeiro de Macedo, as cartas o compõem como sinônimo do "eu" do remetente; no caso dos padres jesuítas, é um "irmão em Cristo" que, obedecendo às normas disciplinares da Companhia, reconhece a doutrina teológico-política aplicada como interpretação das matérias e os procedimentos retóricos que as representam e comunicam. Na circularidade de

28 A carta para o índio Guaquaiba é familiar; nela, Vieira reitera sua amizade com o principal tupi, pergunta-lhe sobre seu estado de saúde e propõe-se a ajudá-lo no que desejar. 
código estabelecida entre a enunciação e a recepção, o destinatário é, assim como o remetente, tipo prudente, honesto e grave, capacitado a traduzir as novidades e dar-lhes sentido por meio dos critérios técnicos e doutrinários comunicados no estilo. A recepção é autoral ou prescritiva: a leitura da carta refaz os procedimentos técnicos aplicados à escrita.

Com exceção da carta escrita para o chefe índio Guaquaíba, destinatário inferior, Vieira sempre aplica os outros dois decoros quando se dirige a destinatários iguais e superiores. Graves, nenhuma de suas cartas tem jocosidades inoportunas, pois dirigem-se a superiores da Companhia, como o Geral Muzzio Vitteleschi e o Geral João Oliva; aos reis D. João IV, D. Afonso vi e D. Pedro II; às rainhas D. Luísa de Gusmão, D. Catarina de Inglaterra e D. Maria Sofia de Neuburg; ao príncipe D. Teodósio; a grandes do Reino, o Marquês de Niza, o Duque de Cadaval, o Conde de Castelo Melhor etc. E a iguais, como amigos seculares e Irmãos da Companhia, tratados sempre discretamente, com extrema cortesia. Excetuando o rei, que é legibus solutus, livre das leis coercitivas do Império - mas não de suas leis morais, pois é rei católico -, o remetente inclui-se a si mesmo e a seus destinatários na totalidade do "corpo místico" como tipos subordinados. Reconhecendo sua posição subordinada, afirma mantê-la em nome do "bem comum". Na relação discursiva estabelecida entre remetente e destinatário, figura-se a esfera pública do Império como totalidade místico-jurídica de indivíduos, estamentos e ordens sociais hierarquicamente subordinados ao rei.

Em todos os casos, como o decoro relaciona-se com as posições institucionais dramatizadas na relação dialógica "eu-tu", Vieira compõe a pessoa do remetente com traços biográficos estilizados como aplicação de um éthos ou caráter constantemente prudente e grave, figurado como posição discreta, avalista e conselheira das restantes posições hierárquicas do Reino. $\mathrm{O}$ remetente tem autoridade para avaliar as matérias porque as vê do ponto de vista da morte, que as artes de prudência de seu tempo prescrevem como ponto fixo que ensina a morrer bem ou "viver com privilégios de morto", como Vieira diz em uma carta de 20 de junho de 1677 para seu amigo, Duarte Ribeiro de Macedo. "Viver com privilégios de morto" significa julgar todas as ocasiões pela perspectiva da caridade que, com o pensamento da morte, torna presentes para o destinatário os fins últimos do homem como desengano da vanitas do grande teatro do mundo. 
Na fórmula "Alguém diz algo sobre alguma coisa para alguém", "dizer algo sobre alguma coisa" corresponde, esquematicamente, a atribuir significação e sentido a tópicas de um referencial determinado. Nas cartas, encontram-se os seguintes estratos:

1: Os lugares-comuns de gênero deliberativo, judicial e demonstrativo aplicados como "questões indefinidas" ou argumentos genéricos para classificar e ordenar as matérias relativas à ação do Império português no Brasil, no Maranhão e GrãoPará, na Ásia, na África e na Europa. Por exemplo, em Esperanças de Portugal, a carta de 29 de abril de 1659 enviada para o Padre André Fernandes, depois Bispo do Japão, a questão indefinida "definição" ("Pela definição se conhece a coisa definida") e a definição particular "O gato significa o Estado da Índia"; a questão indefinida "nome" ("Pelo nome se conhece a coisa nomeada") e a tradução particular: "...e ouvi dizer a seu sobrinho, o Conde de Unhão D. Rodrigo, que seu tio tinha pelo corpo lã como carneiro; por isso Bandarra lhe chama lanudo"; a questão indefinida "propriedade" ("Pela propriedade se conhece a consequência") e a consecução particular: “...disse a S.M. que me espantava muito que S.M. elegesse por Viso-Rei da Índia a um homem de quem o Bandarra dizia mal. Que não lhe podia suceder bem o efeito o mostrou" ou "A verdadeira prova do espírito profético nos homens é o sucesso das cousas profetizadas"; a questão indefinida "termos relacionados" ("De um termo relacionado se infere outro"), e a relação particular entre os termos profeta, profético, profeticamente; o lugar-comum genérico "todo e parte" " Melhor o todo que a parte"; "Se falta uma parte, o todo não é mais todo"; "Pela parte se conhece o todo"), e a inferência particular: "Bandarra diz que este Rei há-de ser levantado no ano de quarenta: e El-rei D. João foi levantado rei no ano de quarenta"; a questão indefinida "pela enumeração das partes se conhece o todo" e a enumeração particularizadora das partes anunciadas por Bandarra e reveladas em D. João IV, que constituem o rei como o Esperado: “[...] e El-rei D. João é semente de El-rei D. Fernando... e El-rei D. João é Rei novo... e El-rei D. João foi levantado rei no ano de quarenta... e El-rei D. João em todo o seu reinado foi felicíssimo... e El-rei D. João [...] sempre teve o mesmo nome... e El-rei D. João logo foi reconhecido por Rei nas conquistas... etc."; a questão indefinida "lei divina" ("É necessário obedecer à lei divina") e, sempre, a afirmação da Causa Primeira providencial que faz a particularidade dos eventos do Império português seus efeitos e signos; a questão indefinida "lei humana" ("O rigor das leis escritas se 
modera com a equidade da lei natural"), e afirmações particularizantes recorrentes, como "Foi logo um lume sobrenatural, profético e divino, o que alumiou o entendimento deste homem idiota e humilde..."; a questão indefinida "ditos de sábios" ("Deve-se acreditar nos ditos de antigos sábios"; "Às vezes mesmo os sábios se enganam", e o recurso contínuo às autoridades particularizadas: "Esta ilação não é só de discurso, senão ainda de fé, porque assim o inferiu Abraão e assim o confirmou S.Paulo....' Etc. Para aplicar esses e mais lugares-comuns, Vieira compõe a narratio - a narração da carta - obedecendo ao critério de representação dos temas por meio das perguntas sobre as circunstâncias principais que o especificam: Quem? Quê? Com quem? Com quê? Como? Onde? Quando? Por quê? No caso de Esperanças de Portugal: Quem? Bandarra. Quê? Profecia. Com quem? Com Isaíase Daniel. Com quê? Com a luz da Graça. Como? Como mistério revelado. Onde? Em Portugal. Quando? No Quinto Império. Por quê? Por causa da Causa Primeira. Deus.

2: Os temas selecionados dos discursos contemporâneos e aplicados como "questões definidas" particulares que preenchem semanticamente as "questões indefinidas" no ato da escrita da carta. Por exemplo, a matéria "guerra contra os holandeses no Nordeste do Brasil" e particularizações como "indenização" e "entrega de Pernambuco"; a matéria "escravidão de africanos" e temas como "posse portuguesa de Angola"; a matéria "defesa do monopólio jesuítico da administração das aldeias indígenas do Maranhão e Grão-Pará" e temas como "colonos escravistas de São Luís do Maranhão" ou "índio de corda"; a matéria "negociação diplomática com a França e os Estados Gerais holandeses" e temas como "entrevista com Mazarino", "casamento de D. Teodósio", "liga antiespanhola"; a matéria "companhias de comércio das Índias Ocidentais e Orientais" e temas como "judeus de Rouen" e "empréstimo de capital pelo cristão-novo André Henriques"; a matéria "conspiração contra a Espanha, oposição ao Santo Ofício da Inquisição, celebração dos reis Bragança como escolhidos de Deus, interpretação profética das trovas do Bandarra" e temas como "ressurreição de D. João IV"; "Quinto Império" etc.

3: Os estilos - simples, médio, humilde, engenhoso etc. - aplicados como adequação das palavras ao gênero, às questões indefinidas, às questões definidas, às circunstâncias, às pessoas e às posições sociais do remetente e destinatário. Vieira costuma escrever períodos redondos, caracterizados pela quantidade medíocre, suavidade dos elementos e propriedade das palavras. No caso, a mediocridade 
corresponde a uma quantidade de palavras e de orações proporcionada à respiração do remetente e à memória do destinatário, que deve ser capaz de recordar, quando termina de ler, se não as palavras, pelo menos o conceito representado do começo ao fim de cada inciso da carta.

A brevidade clara e elegante é própria principalmente de cartas que expõem o estado deliberativo e judicial de uma questão qualquer - por exemplo, a negociação com Holanda, a posição dos coloniais escravistas quanto aos índios do Maranhão, a falta de moeda circulante na Bahia, a destruição do quilombo de Palmares. Definindo e qualificando a causa exposta, esmiúça suas partes para constituir a clara compreensão do destinatário. Muitas figuras patéticas, associadas aos movimentos intelectuais da alma do remetente, são aplicadas persuasivamente no estilo da narração. Por exemplo: cognição (“Sei que..."); ignorância ("Não sei...”); Ostentação ("Vede quantos são..."); narração ("Conto... digo... afirmo"); ensino ("Aprendei que..."); afirmação ("Crede-me..."); negação ("Nego"); ironia ("Nego (para afirmar); afirmo (para negar)"); preterição ("Não direi que..."); juramento ("Juro que..."); atestação ("Dou-vos em testemunho..."); parênteses ("Isto é, se realmente isso for assim, a verdade"); repetição ("A ele aconteceu, ao rei, digo, aconteceu"); exclamação ("Vaidade!"); lembrança ("Na última carta vos dizia que...") etc. Mais figuras patéticas associam-se aos movimentos apetitivos da alma: elogio, saudação, veneração, abominação, irrisão, desejo, voto, recomendação, concessão, agradecimento, recusa, congratulação, lamento, alegria, reprovação, arrependimento, esperança, temor, ameaça, indignação, compaixão, confissão, deprecação etc.

4: O sentido que o remetente propõe para os enunciados. Nas cartas, é corrente a definição ciceroniana da história como magistra vitae, mestra da vida. A tópica funciona como memória exemplar de casos históricos que, pela comparação com as coisas singulares do presente, aperfeiçoam a experiência delas, elevando-as ao universal. Fundamentalmente, o providencialismo, postulação de que na história se lê o desenho ou desígnio da vontade divina; e o profetismo, prognóstico do futuro revelado especularmente em coisas, homens e eventos do passado e do presente. Efetuando esses níveis de sentido pela aplicação de técnicas retóricoteológicas, Vieira recorre a autoridades canônicas da Igreja para interpretar a história humana como allegoria in factis ou alegoria factual. Com a interpretação alegórica, o remetente estabelece concordância analógica entre eventos ou 
homens do Velho e do Novo Testamento e homens e eventos do Império Português, propondo a concordância como figura da Vontade da Providência divina, que escolheu Portugal e a dinastia Bragança como nação e realeza universalizadoras da fé católica.

Vieira subordina a escrita às diretivas para a redação de correspondência estabelecidas em 1547 pelo Pe. Polanco, secretário de Inácio de Loyola, e às determinações sobre cartas especificadas nas Constituições da Companhia de Jesus, publicadas por Loyola em 1556. Imita modelos de gramática e retórica do Ratio studiorum ${ }^{29}$ e aplica preceitos da ars dictaminis, que definem as partes e os estilos da carta: salutatio (saudação), exordium (captatio benevolentiae) (exórdio, captação de benevolência), narratio (argumentatio) (narração, argumentação), petitio (petição), conclusio (conclusão), subscriptio (assinatura).

Sendo gênero dialógico, a carta começa com a salutatio, saudação breve. Hierarquicamente decorosa, é adequada à pessoa do destinatário. Por exemplo, a expressão "Pax Christi", na Ânua de 1626, dirigida ao Geral da Companhia de Jesus, Pe. Muzzio Vitelleschi, e repetida nas demais cartas para jesuítas. Desde a primeira linha, a escrita firma o contrato enunciativo como diálogo inscrito na sacralidade (no caso da "Ânua", o noviço Antônio Vieira inscreve o ato da escrita na Presença divina, compondo-o catolicamente como ocasião de iluminação pela Graça, que participa nele e no destinatário como a sindérese, aconselhando e guiando-os contra a heresia dos holandeses invasores da Bahia. Mais tarde, depois de fazer os votos, manterá a fórmula nas cartas para religiosos da Companhia). No caso, como diz Boureau, a forma da carta reproduz a originalidade essencial do Cristianismo, confirmando que a Encarnação fez Deus vir ao mundo entre homens comuns e que, depois da narrativa do que aconteceu uma vez, o Evangelho, eles dispõem de meios simples para transmitir a boa nova por palavras e ações, como apóstolos ou "enviados."30

O Ratio studiorum determina que, nas aulas ínfimas e médias de gramática (latim), os alunos devem conhecer as cartas familiares de Cícero, principalmente as de Ad familiares. Cf. Ratio studiorum 108: "O tema para a composição, geralmente em forma de carta, será ditado palavra por palavra em língua vulgar e deve referir-se às regras de sintaxe".

30 BOUREAU, Alain. "La norme épistolaire, une invention médievale". In: BOUREAU, Alain; CHARTIER, Roger; DAUPHIN, Cécile; HEBRARD, Jean et alii. La correspondance (Sous la direction de Roger Chartier). Paris: Fayard, 1991, p. 130-1. 
A saudação demonstra que a aplicação do decoro pressupõe o conhecimento sistêmico das adequações do estilo aos diversos níveis hierárquicos de conveniência discursiva e extradiscursiva. As cartas aplicam várias prescrições técnicas do decoro. A primeira delas é, evidentemente, a de evitar a perda do decoro. Quando se dirige ao destinatário na saudação, o remetente lembra Quintiliano: quis et in qua causa et apud quem et in quem et quid dicat ou quem e sobre o quê e em quem e contra quem e o quê diga..$^{31} \mathrm{O}$ modo como saúda o destinatário na abertura da carta e o modo como se despede dele constituem o decoro próprio da sua posição. Uma ordenação filipina de 1597 reservou o tratamento Senhor Dom aos postos mais elevados da burocracia estatal e do clero: arcebispos, bispos, duques e seus filhos, marqueses e condes, o Prior do Crato, vice-reis e governadores, o regedor da justiça da Casa da Suplicação, o governador da Relação do Porto, os vedores da Fazenda, os presidentes do Desembargo do Paço e Mesa de Consciência. Também especificou os usos de tu e vós, de Vossa Mercê, Vossa Excelência, Vossa Reverendissima, Senhor, Senhora etc.

Vieira segue essas pragmáticas no uso das formas de tratamento: Vossa Mercê para fidalgos; Exmo. Senhor para duques e marqueses, como o Duque de Cadaval, o Marquês de Gouveia, o Marquês de Niza; Senhor, para o rei, Senhora, para a rainha, e S.M. (Sua Majestade) e V.A. (Vossa Alteza) para príncipes, princesas, reis e rainhas; $V$. Reverendíssima para Provinciais etc.

O exórdio segue a saudação. Nele, o remetente quase sempre faz referência ao ato de escrever, também fazendo pequenas considerações, prescrições e resumos. Por exemplo:

Exmo. Sr. - A duas de V.Exa. devo resposta, mas acho-me ainda com tão pouco cabedal de saúde, que não sei se poderei responder a ambas: as sangrias foram só quatro, mas a fraqueza é de muitas mais; ${ }^{32}$

Senhor. - Meu Príncipe e meu senhor da minha alma. - Pelos avisos que vão a S.M. entenderá V.A. com que coração escrevo esta, e muito mais com que raiva e com que

31 Quintiliano, De inst. orat., Vl, 3.

32 Carta de 3 de agosto de 1648 ao Marquês de Niza. 
impaciência, vendo-me preso e atado para em tal ocasião ir-me deitar aos pés de V.A., e achar-me a seu lado em todo o perigo; ${ }^{33}$

Pax Christi. Padre e senhor meu. - Exceta a carta a S.A., esta é a única que escrevo a Portugal, e é razão eu o faça assim, porque a singularidade desta lembrança mostre que não desdiz do afeto que sempre conheci dever a V. Revma., e eu me não descuidarei de lho rogar assim, pedindo a V.Revma. me não falte com a mesma lembrança em suas orações e sacrifícios, de que agora tenho mais necessidade. ${ }^{34}$

O exórdio compõe a expectativa plausível do destinatário acerca do que é dito por meio da antecipação do remetente, que fornece código como verossimilhança artificial. O exórdio demonstra a ideia ciceroniana do De oratore: a tarefa básica do discurso é demonstrar a qualidade da matéria tratada. Nele, aparecem lugarescomuns de captatio benevolentiae com que o remetente se autorrepresenta como prudência, humildade e gravidade. É corrente o lugar da captatio benevolentiae breve, com pequenas referências aos pecados, fraqueza, doença, incompetência e inabilidade. Inventado com o éthos de modéstia afetada, que o faz menor que as forças exigidas pelas tarefas evangélicas e políticas, o remetente se heroiciza por persistir na imitação de Cristo reiterando os laços de submissão com um topos da sublimitas in humilitate, "o menor dos servos de Deus" Pela obediência total, demonstra a subordinação perfeita como soldado de Cristo, segundo os dois lemas correntes na Companhia: Perinde ac cadáver (Até à morte) e Na Companhia só se podem desejar duas coisas, a cozinha ou a China. O modelo do remetente é Cristo; com ele, aplica o éthos do ardor de uma fé que se deseja imbativel, à medida mesma que se representa como fraco, incompetente, inábil e pecador. O conceito de "pecado" predetermina o sentido da ação do remetente como causa denegada que lhe permite postular que a natureza humana é perfectível justamente porque é mortal. É da contínua referência ao pecado que extrai a força que o move, dramatizando o discurso como luta perene do autocontrole das paixões direcionado para atingir os fins últimos da "razão de Estado". Assim, todos os seus afetos são

33 Carta de 23 de maio de 1650 ao Príncipe D. Teodósio.

34 Carta de 25 de dezembro de 1652 ao Pe. André Fernandes, SJ. 
empenhados de modo útil, enquanto sofre e faz o destinatário sofrer a catarse propiciada pela narração dos seus sucessos físicos e morais.

Quando o destinatário é um superior da Companhia, como o Pe. Muzzio Vitelleschi; um fidalgo, como o Marquês de Niza, ou pessoas da casa real portuguesa, como D. João IV e o príncipe D. Teodósio, o lugar de exórdio pode estender-se como ato de contrição em que, alegando sua insuficiência, o remetente afirma que em todas as ocasiões da vida sua obediência foi, é e será irrestrita. Como diz na carta de 27 de janeiro de 1648 ao Marquês de Niza:

[...] não me permitiu o meu zelo, nem a confiança que V. Exa. faz de mim, deixar de escrever estas mal entendidas razões, assim como me vieram à pena, se bem não tenho aqui outro cuidado. V. Exa., quando as ler, me perdoará a prolixidade, que o ânimo bem sabe V. Exa. que é de obedecer e servir a V. Exa., e desejar as maiores conveniências do serviço de S.M.

A narratio (discurso, narração) é a parte mais substancial da carta, sendo ordenada conforme os gêneros da correspondência, as matérias e os temas. Se a matéria é histórica, como a da Ânua de 1626, a narração a representa como sucessividade de eventos, em ordem natural, como ocorre nas cartas que expõem as idas e vindas das negociações com os Estados Gerais holandeses, sem possibilidade de confusão das coisas posteriores com as anteriores. Se o discurso faz descrições de coisas naturais, como o inverno holandês, ou artificiais, como a fragata Fortuna, como acontece nas cartas para o Marquês de Niza, a descrição das partes e qualidades das coisas é feita pela aplicação das dez categorias aristotélicas como classes de predicados puros: substância, quantidade, qualidade, relação, lugar, tempo, posição, estado, ação, afecção. As categorias fazem a anatomia ou análise da matéria em dez espécies de temas ou subtemas, constituindo a qualidade dos caracteres e da ação de cada um deles. Quanto mais detalhada é a quaestio finita, o tema particular, mais semanticamente desenvolvida é a quaestio infinita ou o topos aplicado, supondo-se que, para ser verossímil e persuadir, a escrita deve demonstrar a qualidade das matérias. A demonstração da qualidade é essencial para o movere ou a persuasão do destinatário e especifica o quê da matéria, quando o discurso descreve coisas físicas, por meio da apreensão de seus atributos 
sensíveis. ${ }^{35}$ Quando a coisa é ação humana, a qualidade a ser demonstrada é ética; por isso, o que domina na correspondência de Vieira, a questão do quale sit implica, nos casos de relato de ações de personalidades, um status quase sempre relacionado ao certo/errado, regulado prudencialmente pela ética católica. Não de idêntica maneira em todas as situações: ainda que em todo discurso um mesmo procedimento mimético seja aplicado para demonstrar a qualidade, a própria qualidade só tem seu sentido exatamente definido na pragmática determinada na leitura, em que a discrição do leitor entenderá a narração como falsidade, verdade ou verossímil.

A narração apresenta várias matérias justapostas, como determina o decoro do gênero. Cada uma delas costuma ter unidade de estilo, de significação e de sentido, o que permite que sejam retomadas em cartas posteriores. A justaposição de vários incisos coordenados e sintaticamente completos produz a variedade das matérias. A variedade é unificada pela interpretação feita como analogia e semelhança do princípio espiritual que absorve as partes no seu sentido superior explicitado na aequitas da prudência do remetente como doutrina do direito e do dever. Assim, o remetente é "núncio" do fundamento sagrado.

Muitas cartas são epístolas, gênero adequado a matérias argumentativas sérias. É o caso das cartas para Provinciais da Companhia de Jesus; da carta de 1659 para o Bispo do Japão; da Carta Apologética para o Pe. Iquazafigo, em 1686; ${ }^{36}$ e, ainda, de cartas para o rei $D$. João IV, que propõem medidas a serem adotadas na missão do Maranhão e Grão-Pará contra a ação dos coloniais escravistas.

$\mathrm{Na}$ epístola, a brevidade, virtude do estilo na carta familiar, é substituída pela extensão e variedade dos assuntos também determinadas materialmente pela necessidade

35 ARISTOTELES. Physique. Paris: Belles Lettres, 1926, 7.2.-3.

$36 \bigcirc 3^{\circ}$. tomo da edição de João Lúcio d'Azevedo traz dois apêndices. O Apêndice I contém 11 cartas para vários destinatários, inéditas até 1925, 10 delas do tempo em que Vieira esteve na missão maranhense, principalmente para padres da Companhia de Jesus e membros da família real portuguesa; a 11ª de 1668, escrita depois que saiu da prisāo do Santo Ofício, em Coimbra, agradece a amizade constante do Marquês de Gouveia. O Apêndice II é ocupado pela importante Carta Apologética, escrita em castelhano e dirigida ao Padre Jácome lquazafigo, Provincial da Andaluzia, em 30 de abril de 1686. Nela, Vieira novamente defende a interpretação profética das Trovas, de Bandarra, contra o texto Respuesta a una Carta, que Antonio de Vieira Monopanto escrivió à un Señor Obispo de la Orden de los Predicadores, de autoria de um anônimo oculto sob o pseudônimo Escoto Patavino. A Carta Apologética foi publicada em 1757 e a Mesa Censória a proibiu como falsa, sediciosa, temerária e infame, fazendo-a ser queimada por um carrasco, em 1768. 
de aproveitar todas as ocasiões para fornecer informações abundantes. A correspondência sempre depende de improváveis chegadas e partidas de navios e mensageiros, estando exposta a diversos perigos. Deste modo, a falta aparente de unidade produzida pela variação dos assuntos é justificada em outro nível de aptidão, que evidencia a adaptação dos procedimentos retóricos às circunstâncias materiais da escrita e remessa das cartas.

A narração apresenta dois tipos de enunciados, descritivo-narrativos e prescritivos. Os enunciados descritivo-narrativos representam as matérias compondo cenas, quadros, retratos, ações, sequências e eventos justapostos e encadeados segundo a linearidade de "começo-meio-fim". Evidentemente, quando a carta faz referência a um assunto tratado anteriormente, a narratio pode começar em medias res ou ser iniciada com um resumo das principais circunstâncias das coisas já narradas e a lembrança da situação anterior em que a carta foi escrita. Na narração, prescriçōes do gênero das crônicas e cronicões, que montam o discurso como somatório de enunciados justapostos e coordenados, evidenciam o perfeito domínio da técnica adequada para construir a memória dos eventos interpretando-a analogicamente, segundo critérios da racionalidade escolástica. Por ter a similitude como fundamento, a enunciação pode projetar em todo elemento novo, justaposto ou coordenado, a unidade comum da Significação transcendente, como luz da Graça que se refrata nele, enquanto o absorve em sua Providência.

Em geral, a enunciação especifica o estado deliberativo dos temas, discutindo-os segundo a previsão da ação futura. Aqui, como qualidade moral projetada participativamente nos atos enunciativos e nos enunciados, o éthos do remetente desenha-se na escrita como um análogo do universal do sublime da Fé já prefigurado nos casos retóricos que, ao serem repetidos, tornam legal e legítima a decisão que aconselha. ${ }^{37}$ Quanto aos enunciados prescritivos, fornecem orientação pragmático-semântica sobre o modo como o destinatário deve interpretar e incorporar o que é dito. Geralmente, a enunciação quase não os comenta, evidenciando que remetente e destinatário consideram a prescrição óbvia, universal e justa: a verdade do dogma católico, a crença na justiça de evangelizar o gentio, o silêncio sobre a escravidão africana,

37 "Universal" como na Poética: a espécie de coisa que um tipo determinado de um gênero determinado deve dizer ou fazer segundo a probabilidade e a necessidade. 
a justiça da luta portuguesa contra a Espanha e os Estados Gerais holandeses etc. são naturalmente contrapostos à heresia calvinista e às práticas de índios e negros como evidência indiscutível de que o remetente e o destinatário participam de uma razão universal, lógica, caritativa e justa. Assim, o remetente também especifica o estado judicial dos temas, interpretando a narração deles com a doutrina ético-jurídica de certo/errado fundamentada teologicamente nos dogmas contrarreformados. Com isso, especifica também a equidade verossímil do seu "eu" que, ao evitar a elocução ornada, prefere o sentido próprio do estilo sem atavios para construir a fala grave, apta para julgar os assuntos e mover e persuadir evangelicamente o destinatário quanto à universalidade do sublime de sua Causa Eficiente e Final.

Assim, a tópica da lei natural da Graça inata é nuclear na narração. Ela permite que o remetente determine não só a legalidade, mas principalmente a legitimidade de ações e eventos, em termos ético-políticos fundamentados na teologia católica da lei eterna. Segundo o remetente, a lei natural se expressa nas leis positivas e imperativas do Império fundadas no Direito Canônico aplicado por funcionários reais e pelo Padroado. Desta maneira, a equidade ético-retórica do caráter prudente da sua enunciação é sempre política, observando-se que a unidade do sentido teológico geral da ação narrada é distribuída nos enunciados em feixes de codificações institucionais que a fazem evidente, legal e legítima.

Terminada a narração, segue-se a petitio, parte final em que se fazem pedidos ou se reiteram as solicitaçōes feitas desde o início da carta. A petitio das cartas de Vieira pressupõe as relações corporativas do "corpo místico" do Império que determinam a relação do remetente e destinatário e os temas da narratio. Fazendo o pedido, o remetente está em situação de inferioridade e, para não ferir o decoro, parecendo excessivo, impertinente, néscio, arrogante ou supérfluo, deve acompanhá-lo de razões que o justifiquem, principalmente quando o destinatário é pouco conhecido ou de condição superior. Tratando-se de um amigo, deve-se confiar em seu caráter e amizade. Para justificar o pleito, o remetente recorre a tópicas epidíticas, como origem, pátria, educação, nome de família, posição, amizades e inimizades comuns, serviços prestados, honra etc., qualificando-se com elas para qualificar o pedido. Deste modo, na petitio mais uma vez se encenam os decoros hierárquicos. A natureza das coisas pedidas é infinita, pois o remetente é homem, ser contingente, refém da necessidade. Mas Vieira diz não ter pleitos e afirma amar só por 
amar. Quando pede, é para favorecer amigos e parentes. Mas tenta a intercessão de poderosos no processo que a Inquisição lhe move. Em uma carta para a rainha D. Catarina de Inglaterra, de 21 de dezembro de 1669, escreve:

O Cardeal Francisco Barbarino é o Presidente do tribunal, em que há-de correr a minha causa. Se, como Protetor dos reinos de V.M., V.M. lhe mandasse escrever uma carta, em que V.M. lhe encomendasse muito favorecesse, com particular assistência, os negócios que tenho nesta Cúria, seria para mim a melhor mercê que da Real casa de V.M. recebi em minha vida, pois não me importa menos que a honra. ${ }^{38}$

A conclusão é feita de três maneiras básicas, como prescreve Fabri: por amplificação, como que induzindo o destinatário à ira; por comiseração, como que o comovendo à piedade; e por epílogo, como que recolhendo brevemente o que foi longamente espalhado antes, na narração. ${ }^{39}$ Quase sempre, Vieira escreve a conclusão aplicando afetos que reiteram a gravidade do remetente - nas cartas do fim da vida, sua amargura e solidão - com que reconfirma os laços de união em Cristo, com destinatários da Companhia de Jesus; de amizade, com iguais; e de subordinação, com destinatários reais e grandes do Império. Em todos os casos, aplica decoros adequados à posição do destinatário: suma reverência, absoluta submissão, votos de grandeza, glória e felicidade, proteção divina e vida longa para os poderosos do Reino; amizade e felicidade para iguais; amizade, para inferiores, como o índio Guaquaíba. Em todos os casos, prevê o que Emanuele Tesauro prescreve: deve-se honrar abundantemente a todos, pois pode acontecer que se venha a ter necessidade de todos..$^{40}$ Por exemplo, em carta de 24 de junho de 1691 a Francisco de Brito Freire, Conselheiro de Guerra e Almirante da Armada Real:

39 Cf. FABRI, Pierre. Le grand et vrai art de pleine rhétorique. Introd., notes et glossaire par A. Héron. Genève: Slaktine Reprints, 1969, p. 291.

40 "Oltre che, un' Huomo, potendo haver bisogno di tutti gli Huomini, ad abondanti tutti deve honorare". In: TESAURO, Emanuele. Dell' Arte delle lettere missive del Conte e Cavalier Gran Croce D. Emanuele Tesauro, Patritio Torinese Vindicata dall' Oblivione, et Dedicata al Sereníssimo Príncipe Di Piemonte etc. Bologna: Per Gio: Recaldini, 1678, p. 362. 
Para anacoreta de um deserto me tenho alargado muito fora da minha profissão; mas quem há-de tapar a boca ao amor da pátria, e mais falando com V.Sa.? V.Sa. me guardará segredo, e eu, como mais próprio do meu estado, não faltarei à obrigação de rogar a Deus pela felicidade e vida de V.Sa., que sua Divina Majestade prospere por muitos anos como desejo.

A subscriptio ou assinatura vem depois da data e de uma qualificação do remetente como amigo e serviçal do destinatário: "Baía, 2 de Maio de 1686. De V. Mercê humilde capelão e obrigadíssimo servo." Antônio Vieira.

Desta maneira, tratando de questões do Estado do Brasil e do Maranhão e GrãoPará, como a guerra contra os Estados Gerais holandeses e a escravidão indígena, ou de questões da política europeia, como a guerra contra a Espanha e a ação do Santo Ofício da Inquisição, as cartas de Vieira são práticas simbólicas ativamente constitutivas da doutrina católica do poder da monarquia portuguesa.

João Adolfo Hansen é professor de Literatura Brasileira da Universidade de São Paulo e autor de Carlos Bracher. A mineração da alma [Edusp, 1998]; O O - A ficção da literatura em Grande sertão: veredas [Hedra, 2000]; Cartas do Brasil - Antônio Vieira [Org.] [Hedra, 2003]; A sátira e o engenho. Gregório de Matos e a Bahia do século XVII [Ateliê Editorial, 2004]; Solombra ou a sombra que cai sobre o eu [Hedra, 2005]; Alegoria: construção e interpretação da metáfora [Hedra, 2006]. 